\title{
INVESTIGATION, SIMULATION AND COMPARISON OF VARIOUS ROUTES FOR BIOETHANOL PRODUCTION
}

\author{
LETITIA PETRESCU ${ }^{\mathrm{a}^{*}}$, ANA-MARIA POSA ${ }^{\mathrm{a}}$
}

\begin{abstract}
Bioethanol has proven its value as an alternative fuel to gasoline, in fact, more as an adding than a competitor. Bioethanol has attracted a lot of interest due to its biodegradable nature, low cost, low toxicity and safety. The present work is focused on process modelling and simulation of bioethanol production using biomass and / or $\mathrm{CO}_{2}$ and $\mathrm{H}_{2}$ as raw-materials. The first scenario investigated considers the biomass fermentation, the second scenario considers the thermo-catalytic hydrogenation of $\mathrm{CO}_{2}$ while the combination of the previously methods was assumed in the third scenario. The main advantages of these routes are the reduction of greenhouse gas emissions and the production of one valuable chemical, bioethanol. A productivity of 30,000 tones/year of bioethanol is set for all three cases. Purities, higher than $90 \%$ for the main product, are obtained. The technical comparison of the three scenarios leads to the conclusion that the best option to obtain bioethanol is from cellulosic biomass. In this first case, the energy consumption is $0.08 \mathrm{~kW} /$ $\mathrm{kg}$ bioethanol and the carbon dioxide emissions are $0.96 \mathrm{~kg} \mathrm{CO}_{2} / \mathrm{kg}$ bioethanol being much lower than in the other two considered cases.
\end{abstract}

Keywords: Bioethanol production, process modelling and simulation, technical comparison

\section{INTRODUCTION}

Renewable energy has gained great importance nowadays, given the problem of environmental concerns and the increased demand for energy. Bioethanol is one of these renewable energy types, which became more and more attractive in the recent years. Bioethanol production and its use as an alternative fuel have a long story, being hard to explore when humans exactly started this production from the solid feed-stock. Compared to the conventional

\footnotetext{
a Department of Chemical Engineering, Babeş-Bolyai University, Faculty of Chemistry and Chemical Engineering, 11 Arany Janos str., RO-400028, Cluj-Napoca, Romania.

*Corresponding author: letitiapetrescu@chem.ubbcluj.ro
} 
fuels (e.g. gasoline), ethanol is able to reduce emissions of particulate matter, toxic chemicals, and greenhouse gasses when it is used in cars engines [1]. The most important characteristic of ethanol, which makes it suitable as a fuel for Otto and diesel engines, is its high octane number [2]. Using bioethanol on a large scale will minimize evaporative emissions, minimizing its impact on the greenhouse gas effect by up to $61 \%$ compared to gasoline [3, 4]. Beside a higher octane number it also presents a broader flammability limits, higher flame speeds and higher heats of vaporization than gasoline, thus, allowing for higher compression ratio, shorter burn times and leaner burn engines [5]. Obtaining bioethanol by fermentation can reduce the carbon dioxide emissions because the biomass used in its production is considered to be carbon neutral. Its cycle, from crops to $\mathrm{CO}_{2}$ usage, is presented in Figure 1.

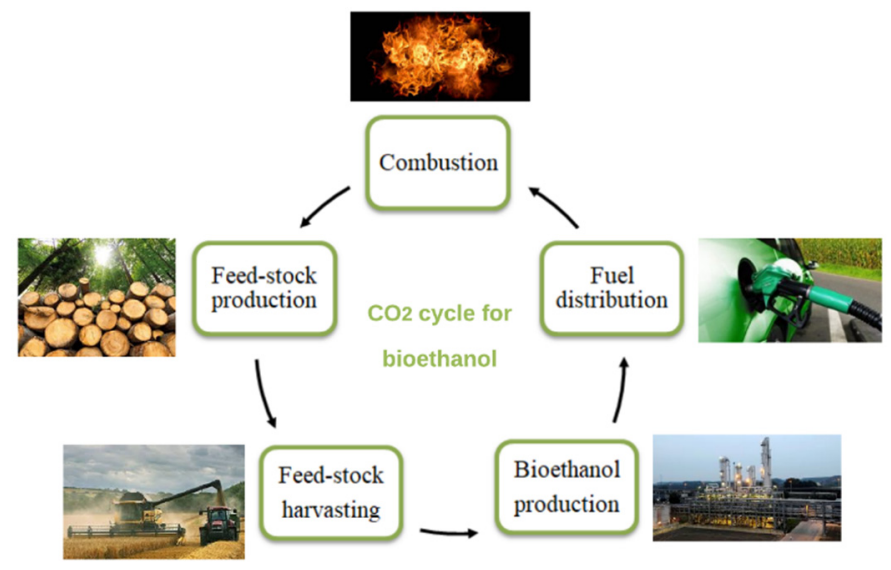

Figure 1. Bioethanol cycle

Balat and co-authors presents also some disadvantages of bioethanol such as: its corrosiveness, low flame luminosity and miscibility with water [5].

There are two types of ethanol industrially produced: synthetic ethanol and fermentation ethanol. Synthetic ethanol is obtained artificially from petrochemical raw-materials, generally by the hydration reaction of ethylene. To achieve a high-quality alcoholic product, the synthesis is performed based on the reaction between ethylene and water, ethylene being produced in refineries. For instance, about $85 \%$ of ethanol produced in the United States comes from a fermentation process, but the remaining amount comes from the catalytic hydration in the gas phase of ethylene [6]. Fermentation ethanol or bioethanol can be produced from biomass materials containing sugars, starches or cellulose. The fermentation step is necessary 
to convert the sugar into ethanol. It will be followed by a more or less advanced distillation step to separate the alcohol from the water. According to European Renewable Ethanol the main raw-materials used for bioethanol production in Europe are: corn with $43 \%$, wheat with $26 \%$, sugars with $21 \%$ followed by other cereals (e.g. 6\%) and ligno-cellulosic raw-materials (e.g. wood chips with 4\%) [7]. The raw-materials for cellulosic biomass is widely available, it can grow on poor quality marginal land with less water and fertilizer and does not compete with food crops. Cellulosic biomass can be obtained from a variety of sources such as agricultural residues (i.e. corn stover, sugar cane, etc.), agricultural raw-materials grown as energy crops (i.e. switch grass, etc.), forest residues (i.e. fallen branches, leaves, sawdust, etc.), municipal solid waste (i.e. paper and cardboard products) and industrial waste (i.e. sludge for manufacturing paper) [8]. The technology for converting various types of biomass into ethanol is constantly improving and also competes with gasoline production, in terms of costs. Cellulose biomass must be very well prepared to produce fermentable sugars, to obtain as much ethanol as possible [9]. Instead of chemical synthesis, the fermentation process of simple sugars, mostly glucose, will be used to produce ethanol from biomass, especially waste biomass.

Biomass conversion methods to various products are represented in Figure 2. There are three main routes for the production of biofuels from biomass, one involving thermochemical processing, the second one involving biochemical processing and the last one involving physical processing [10].

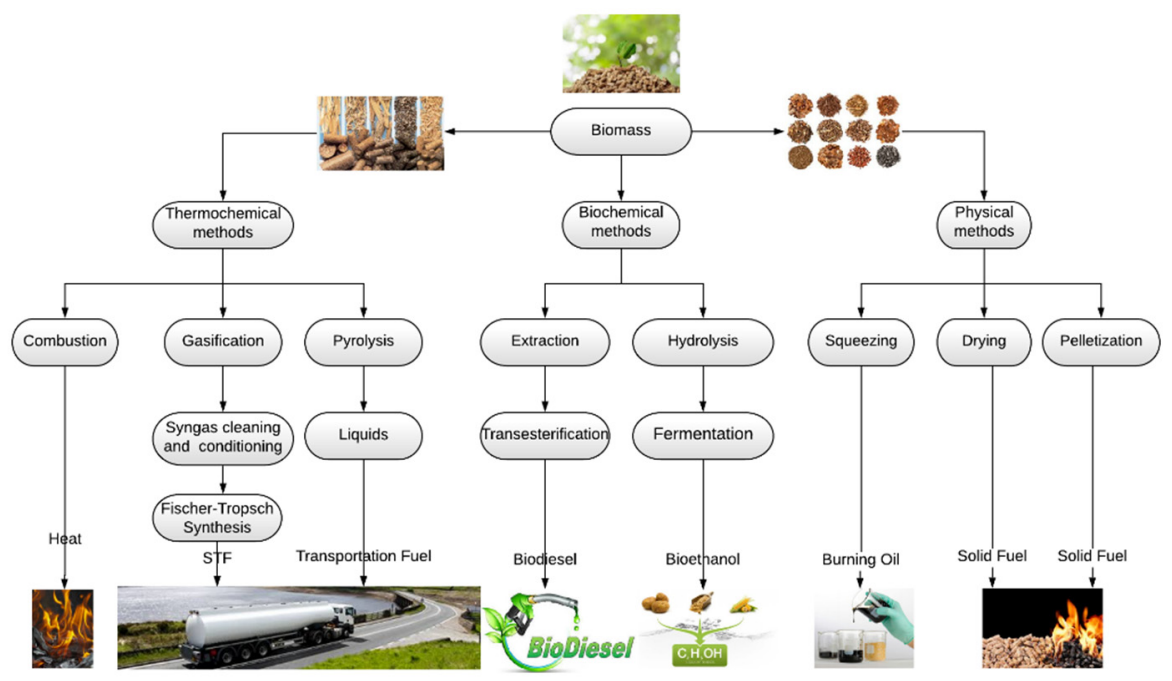

Figure 2. Biomass conversion routes 
"Thermo" processing defines the conversion of biomass into a range of products, by thermal decay and chemical reformation, and essentially involves heating biomass in the presence of different oxygen concentrations. Thermal processes are sufficient in terms of energy because the energy required to heat the biomass up to the requested temperatures can be supplied by the partial or total oxidation of carbon from the biomass, reactions that are usually very exothermic [11].

Biochemical conversion of cellulose into ethanol occurs in three stages, pre-treatment, hydrolysis and fermentation. In general, the purpose of pretreatment is to weaken the structure of the plant cell wall and to improve the access of hydrolytic enzymes to sugar polymers. The raw- material is subjected to mechanics or thermochemical treatment to make the carbohydrate polymers necessary for hydrolysis. Cellulose and hemicellulose must be separated from the lignin, this being possible either by physical and chemical and / or biological pre-treatment. No physical substances are involved in physical pre-treatment. The addition of dilute acid and high-pressure steam, so-called acid-catalysed steam explosion, can improve the enzymatic hydrolysis of cellulose. If pre-treatment takes place chemically, some concentrated or dilute acids will be added to the raw-material. However, concentrated acids are toxic, corrosive, and must be recovered after the process. Therefore, dilute acid hydrolysis has been used instead of many applications, having a high reaction rate and efficient hydrolysis of cellulose [12,13]. This step is followed by hydrolysis. Water molecules react with the bonds in the structure of cellulose and hemicellulose and degrade them in sugar units such as glucose, xylose, etc. Mineral acids (i.e. sulphuric, hydrochloric, and nitric acid) are used for this process in concentrations between 0.5 and $1.5 \%$ [14]. Hydrolysis is usually performed at $100-240^{\circ} \mathrm{C}$ and lasts 2 10 minutes. The production of fermentable sugars by acid hydrolysis is between $75-90 \%$. Hydrolysis can also be enzymatic. In enzymatic hydrolysis, the structure of cellulose is converted into glucose by enzymes. The biomass must first be treated with a short, diluted step of acid hydrolysis, in which the cellulose structure is disturbed and the hemicellulose decomposes into fermentable sugars. The cellulose is then broken down into cellobiose, which in turn is broken down into glucose. Optimal enzyme activity and optimal reaction conditions such as temperature (e.g. $45-50^{\circ} \mathrm{C}$ ) and $\mathrm{pH}$ (e.g. 4.8) will increase the ethanol yield. The best method to produce ethanol from biomass is the application of enzymatic hydrolysis [15]. When the sugars have been released, fermentation takes place. The anaerobic bacteria used at this stage to convert sugars (both glucose and xylose) into ethanol is Zymomonas mobilis. During the fermentation process, it is important to separate the ethanol produced from the initial liquid, as many microorganisms may not survive the high concentration of ethanol. It is also necessary to separate the solid residue (including lignin) from the liquid mixture. From the remaining liquid containing ethanol, water, and other compounds, the desired product can be separated by distillation [15]. 
The present paper aims to model, simulate and compare, in the ChemCAD 7 software, different technologies for bioethanol production. Cellulosic biomass for the first process respectively carbon dioxide and hydrogen for the second process, and a combination of biomass, carbon dioxide and hydrogen for the third case are proposed as raw-materials for the technologies under investigation. The productivity of the bioethanol plant was set to $3681 \mathrm{~kg} / \mathrm{h}$, the equivalent of 30,000 tons/year.

\section{RESULTS AND DISCUSSION}

The case studies investigated in the present work are:

Case 1: Bioethanol from biomass production;

Case 2: Bioethanol from $\mathrm{CO}_{2}$ and $\mathrm{H}_{2}$;

Case 3: Bioethanol from biomass coupled with bioethanol from $\mathrm{CO}_{2}$ and $\mathrm{H}_{2}$.

A schematic representation of the cases under study is illustrated in Figure 3, Figure 4 and Figure 5 under the EXPERIMENTAL SECTION.

Main input and output streams from process modelling and simulation of bioethanol production from biomass (Case 1) are centralized in Table 1 and Table 2.

Table 1. Main inputs for bioethanol production from biomass (Case 1)

\begin{tabular}{|c|c|c|c|c|c|}
\hline \multirow[t]{2}{*}{ Parameters } & \multirow{2}{*}{$\begin{array}{c}\text { Unit of } \\
\text { measure }\end{array}$} & \multicolumn{4}{|c|}{ Streams } \\
\hline & & Feed-stock & Acid feed & Enzyme feed & Inoculum feed \\
\hline Pressure & atm & 1 & 4 & 1 & 1 \\
\hline Temperature & ${ }^{\circ} \mathrm{C}$ & 45 & 745 & 20 & 41 \\
\hline Vapour fraction & - & - & 1 & - & - \\
\hline Liquid fraction & - & 1 & - & 1 & 1 \\
\hline \multicolumn{6}{|l|}{$\begin{array}{l}\text { Component } \\
\text { mass flow-rate }\end{array}$} \\
\hline Water & \multirow[t]{10}{*}{$\mathrm{kg} / \mathrm{h}$} & $6,284.33$ & $13,719.50$ & 873.38 & $4,730.80$ \\
\hline Sulphuric acid & & - & 402.13 & - & - \\
\hline Cellulose & & $4,353.38$ & - & - & - \\
\hline Hemicellulose & & $3,200.88$ & - & - & - \\
\hline Lignin & & $2,094.73$ & - & - & - \\
\hline Acetate & & 340.00 & - & - & - \\
\hline Enzyme & & - & - & 79.31 & - \\
\hline Z. mobilis & & - & - & - & 26.95 \\
\hline DAP & & - & - & - & 18.99 \\
\hline CSL & & - & - & - & 151.78 \\
\hline Total flow-rate & $\mathrm{kg} / \mathrm{h}$ & $16,273.32$ & $14,121.63$ & 952.69 & $4,928.52$ \\
\hline
\end{tabular}

DAP - Di-ammonium Phosphate; CSL - Corn Step Liquor 
Table 2. Main outputs for bioethanol production from biomass (Case 1)

\begin{tabular}{|c|c|c|c|c|c|}
\hline \multirow{2}{*}{ Parameters } & \multirow{2}{*}{$\begin{array}{l}\text { Unit of } \\
\text { measure }\end{array}$} & \multicolumn{4}{|c|}{ Streams } \\
\hline & & \begin{tabular}{|c|}
$\begin{array}{c}\text { Output } \\
\text { from } \\
\text { reactor } 3\end{array}$ \\
\end{tabular} & Wastewater & Bioethanol & $\begin{array}{c}\mathrm{CO}_{2} \\
\text { stream }\end{array}$ \\
\hline Pressure & atm & 1 & 1 & 1.91 & 4.76 \\
\hline Temperature & ${ }^{\circ} \mathrm{C}$ & 41 & 101.93 & 90.97 & 60 \\
\hline Vapour fraction & - & - & 1 & - & 1 \\
\hline Liquid fraction & - & 1 & 0 & 1 & - \\
\hline \multicolumn{6}{|l|}{$\begin{array}{l}\text { Component mass } \\
\text { flow-rate }\end{array}$} \\
\hline Water & \multirow[t]{17}{*}{$\mathrm{kg} / \mathrm{h}$} & $2,2637.80$ & $4,457.93$ & 303.65 & 63.38 \\
\hline $\mathrm{CO}_{2}$ & & $3,490.86$ & - & - & $3,490.86$ \\
\hline $\mathrm{O}_{2}$ & & 31.78 & - & 0.01 & 31.78 \\
\hline Sulphuric acid & & 402.13 & - & - & - \\
\hline Glucose & & 105.14 & - & - & - \\
\hline Xylose & & 255.72 & - & - & - \\
\hline Cellulose & & 191.41 & - & - & - \\
\hline Hemicellulose & & 80.02 & - & - & - \\
\hline Lignin & & $2,094.73$ & - & - & - \\
\hline Furfural & & 64.15 & 52.25 & 0.04 & - \\
\hline Cellobiose & & 50.51 & - & - & - \\
\hline Glycerol & & 29.01 & - & - & - \\
\hline Succinic acid & & 75.66 & - & - & - \\
\hline Acetic acid & & 374.45 & 81.22 & - & - \\
\hline Lactic acid & & 15.87 & - & - & - \\
\hline Xylitol & & 156.86 & - & - & - \\
\hline Bioethanol & & $3,683.70$ & - & $3,681.50$ & 2.04 \\
\hline Total flow-rate & $\mathrm{kg} / \mathrm{h}$ & $33,739.80$ & $4,591.40$ & $3,985.20$ & $3,588.06$ \\
\hline
\end{tabular}

As noticed from Table 1, the quantity of biomass introduced into the system is $16,273.32 \mathrm{~kg} / \mathrm{h}$. In addition to the biomass raw-material, water, catalyst, steam, enzyme, and inoculum flows are also added. The outputs of the system, which include the desired amount of bioethanol (e.g. $3,681.5 \mathrm{~kg} / \mathrm{h}$ ), are reported in Table 2. All by-products will be recycled into the system, except for water, which is sent to the wastewater treatment plant, and $\mathrm{CO}_{2}$. Table 3 presents the validation of the proposed model. 
INVESTIGATION, SIMULATION AND COMPARISON OF VARIOUS ROUTES FOR BIOETHANOL PRODUCTION

Table 3. Model validation for bioethanol production process (Case 1)

\begin{tabular}{|l|c|c|}
\hline \multirow{2}{*}{ Stream name } & $\begin{array}{c}\text { Outputs stream } \\
\text { (simulation) }\end{array}$ & Literature [16] \\
\cline { 2 - 3 } & Bioethanol output & Bioethanol output \\
\hline Components flows & ton/h & ton/h \\
\hline Water & 34.10 & 34.21 \\
\hline $\mathrm{CO}_{2}$ & 25.00 & 25.00 \\
\hline Bioethanol & 26.36 & 22.75 \\
\hline Total mass flow & 85.46 & 82.01 \\
\hline
\end{tabular}

From the ChemCAD simulation performed during this study it can be concluded that starting from a quantity of 114.34 tons/h of cellulosic biomass, a quantity of 26.36 tons/h of bioethanol (with $92.38 \%$ purity) was obtained. Data from the literature indicate a flow rate of 22.75 tons/h bioethanol, $99 \%$ purity. Calculating the error between the data obtained in the simulation and those in the literature, an error of less than $3 \%$ is obtained, which allows us to state that there is a very good concordance between the two data sets. After the model was validated, it was updated to the desired bioethanol production capacity (e.g. 3.68 tons/h).

The inputs and output streams for bioethanol production from $\mathrm{CO}_{2}$ and $\mathrm{H}_{2}$ (Case 2) are summarized in Table 4.

Table 4. Main inputs \& outputs for bioethanol production from $\mathrm{CO}_{2} \& \mathrm{H}_{2}$ (Case 2)

\begin{tabular}{|c|c|c|c|c|c|}
\hline \multirow[t]{2}{*}{ Parameters } & \multirow{2}{*}{$\begin{array}{c}\text { Unit of } \\
\text { measure }\end{array}$} & \multicolumn{4}{|c|}{ Streams } \\
\hline & & $\mathrm{CO}_{2}$ & $\mathrm{H}_{2}$ & Bioethanol & $\begin{array}{l}\text { Waste } \\
\text { water }\end{array}$ \\
\hline Pressure & atm & 24.67 & 24.67 & 0.19 & 0.98 \\
\hline Temperature & ${ }^{\circ} \mathrm{C}$ & 50 & 50 & 39.59 & 46.25 \\
\hline Vapour fraction & - & 1 & 1 & - & - \\
\hline Liquid fraction & - & - & - & 1 & 1 \\
\hline $\begin{array}{l}\text { Component mass } \\
\text { flow-rate }\end{array}$ & & & & & \\
\hline $\mathrm{CO}_{2}$ & $\mathrm{~kg} / \mathrm{h}$ & $18,369.29$ & - & 23.78 & 10.56 \\
\hline $\mathrm{H}_{2}$ & & - & $2,510.71$ & 0.21 & 0.16 \\
\hline $\mathrm{CO}$ & & - & - & 0 & 0.71 \\
\hline Dimethyl ether & & - & - & 110.13 & 0 \\
\hline Methanol & & - & - & 33.32 & 133.45 \\
\hline Ethanol & & - & - & $3,681.91$ & 192.68 \\
\hline Water & & - & - & 77.84 & $8,154.48$ \\
\hline Total flow-rate & $\mathrm{kg} / \mathrm{h}$ & $18,369.29$ & $2,510.71$ & $3,927.19$ & $8,492.04$ \\
\hline
\end{tabular}


The quantity of the raw-material introduced into the system (i.e. $\mathrm{CO}_{2}$ and $\mathrm{H}_{2}$ ) is $20,880 \mathrm{~kg} / \mathrm{h}$. The outputs of the plant, which include the desired amount of bioethanol (e.g. 3,681.9 kg/h), are also reported in Table 4. Model validation is summarized in Table 5.

Table 5. Model validation for bioethanol production process (Case 2)

\begin{tabular}{|l|c|c|}
\hline \multirow{2}{*}{ Stream name } & Outputs stream (simulation) & Literature [17] \\
\cline { 2 - 3 } & Bioethanol output & Bioethanol output \\
\hline Components flows & ton/h & ton/h \\
\hline Methanol & 0 & 0 \\
\hline Water & 0 & 0 \\
\hline Bioethanol & 2.50 & 2.51 \\
\hline Total mass flow & 2.50 & 2.51 \\
\hline
\end{tabular}

In the first step, after building the model this was compared with a literature model. The simulation results show that starting from a quantity of 20.88 tons $/ \mathrm{h}$ of $\mathrm{CO}_{2}$ and $\mathrm{H}_{2}$, a quantity of 2.50 tons/h of ethanol is obtained, with $99.80 \%$ purity. Literature data indicate a flow rate of 2.51 tons $/ \mathrm{h}$ ethanol, with $100 \%$ purity. Calculating the error between the data obtained in the simulation and those in the literature, an error of less than $3 \%$ is obtained, which allows us to state that there is a very good concordance between the two data sets. After the model was validated it was updated to the desired ethanol flow-rate (e.g. 3.68 tons $/ \mathrm{h}$ ), rescaling all the inputs streams.

Case 3 represents a combination of the first two cases. The $\mathrm{CO}_{2}$ generated within Case 1 combined with $\mathrm{H}_{2}$ from water electrolysis, electricity for water electrolysis being generated using renewable sources (i.e. biomass, wind, photovoltaic) leads to additional bioethanol. Therefore, using a smaller amount of biomass, more exactly $13,879.51 \mathrm{~kg} / \mathrm{h}$ a quantity of $3,140.50 \mathrm{~kg} / \mathrm{h}$ bioethanol and $2,976.02 \mathrm{~kg} / \mathrm{h} \mathrm{CO}_{2}$ will be generated. The $\mathrm{CO}_{2}$ captured together combined with a $\mathrm{H}_{2}$ stream, will generate an additional amount of bioethanol, more precisely $541.50 \mathrm{~kg} / \mathrm{h}$. The total amount of bioethanol generated within the combined technologies case will be about $3682 \mathrm{~kg} / \mathrm{h}$.

A comparison of the three cases analysed in the present research study is presented in Table 6 . 
INVESTIGATION, SIMULATION AND COMPARISON OF VARIOUS ROUTES FOR BIOETHANOL PRODUCTION

Table 6. Comparison of the three cases of bioethanol production

\begin{tabular}{|l|c|c|c|}
\hline Case no. & Case 1 & Case 2 & Case 3 \\
\hline Raw materials & Biomass & $\mathrm{CO}_{2}+\mathrm{H}_{2}$ & $\begin{array}{c}\text { Biomass \& } \\
\left(\mathrm{CO}_{2}+\mathrm{H}_{2}\right)\end{array}$ \\
\hline Mass flow-rate $[\mathrm{kg} / \mathrm{h}]$ & $16,273.32$ & $20,880.00$ & $17,262.50$ \\
\hline Main product & \multicolumn{3}{|c|}{ Bioethanol } \\
\hline Molar-flow-rate $[\mathrm{kmol} / \mathrm{h}]$ & 79.91 & 79.92 & 79.92 \\
\hline Mass flow-rate [kg/h] & $3,681.50$ & $4,681,91$ & $3,682.00$ \\
\hline Ethanol Purity [\%] & 92.38 & 94.00 & 93.00 \\
\hline $\begin{array}{l}\text { Energy consumption } \\
\text { [kW / kg ethanol] }\end{array}$ & 0.08 & 1.97 & 0.36 \\
\hline $\begin{array}{l}\mathrm{CO} / 2 \text { emissions } \\
{[\mathrm{kg} \mathrm{CO} / \mathrm{kg} \text { ethanol] }}\end{array}$ & 0.95 & 3.36 & 1.30 \\
\hline Equipments no. & 15 & 42 & 57 \\
\hline
\end{tabular}

The simulation for the third case, called Case 3, indicates that starting from a quantity of 17.26 tons/h of biomass and $\mathrm{CO}_{2}$ and $\mathrm{H}_{2}$, a quantity of 3.68 tons/h of ethanol is obtained, with $93 \%$ purity. Comparing all three cases investigated, as seen in the above mentioned table, the goal of obtaining the same amount of main product is achieved. It results that the best process to obtain bioethanol is from biomass. The first case, Case 1, determines purity higher than $90 \%$ of the main product, lower energy consumption and lower carbon dioxide emissions than in the other two cases studied.

According to the scientific literature [17], the cost of ethanol production from corn stover is about 0.56 euro/l while the ethanol production from $\mathrm{CO}_{2}$ is around 1.33 euro/l. Even if the ethanol production price from corn stover is expected to rise in the near future more effort should be paid by the $\mathrm{CO}_{2}$ utilization route in order to be competitive with the bio-based routes. The technical, environmental as well as economic aspects stress once more the benefits of obtaining bioethanol from corn stover.

\section{CONCLUSIONS}

The present work aimed at modelling and simulation of three production plants of 30,000 tons/year of bioethanol, starting from different raw-materials. Bioethanol production from cellulosic biomass (i.e. corn stover) was compared to bioethanol production obtained from thermo-catalytic hydrogenation of $\mathrm{CO}_{2}$ and with a third method consisting of a combination of the above 
mentioned two cases. The three processes were modelled and simulated in the ChemCAD software program version 7.1.5. The obtained models were validated using data from the scientific literature, observing a good correlation between the simulated data sets and those presented by the scientific literature, the error between them being less than 3\%. After models validation they have been adapted to the desired productivity. The desired purity of the final product was over $90 \%$. In the case of the bioethanol production from biomass, a purity of $92.38 \%$ bioethanol was obtained; in the case of the thermo-catalytic hydrogenation process of carbon dioxide a purity of $94 \%$ was obtained, while in the third case the purity was $93.00 \%$. In addition, for comparison of the three cases, beside the purity of the main product, other parameters such as specific energy consumption or $\mathrm{CO}_{2}$ emissions should be considered. Therefore, as can be deuced from the previous data, the amount of energy required for the operation of the plant in the first case is $0.08 \mathrm{~kW} /$ $\mathrm{kg}$ ethanol. The second case has an energy requirement of $1.97 \mathrm{~kW} / \mathrm{kg}$ ethanol and the third case of $0.36 \mathrm{~kW} / \mathrm{kg}$ ethanol. The lowest $\mathrm{CO}_{2}$ emissions are registered in the first case. The value is 0.29 times lower than the value obtained in the second case and 0.74 times lower than the value obtained in the third case. Having all the necessary data for a comparison between the three cases, it results that the best method to obtain bioethanol is represented by Case 1 , by using a biomass raw-material of 16.27 tons/h.

\section{EXPERIMENTAL SECTION}

\section{GENERAL PRESENTATION}

In the present study, the raw-material used in the production of bioethanol is represented by the residues left on the field after the corn harvest. The main compounds of this biomass are cellulose, hemicellulose, and lignin. As mentioned above, there are three pathways to obtain bioethanol: biochemical, thermochemical and physical. The biochemical pathway was used in this study, which is based on the presence of microorganisms and enzymes. The flow-sheet of the bioethanol production process is presented in Figure 3. 


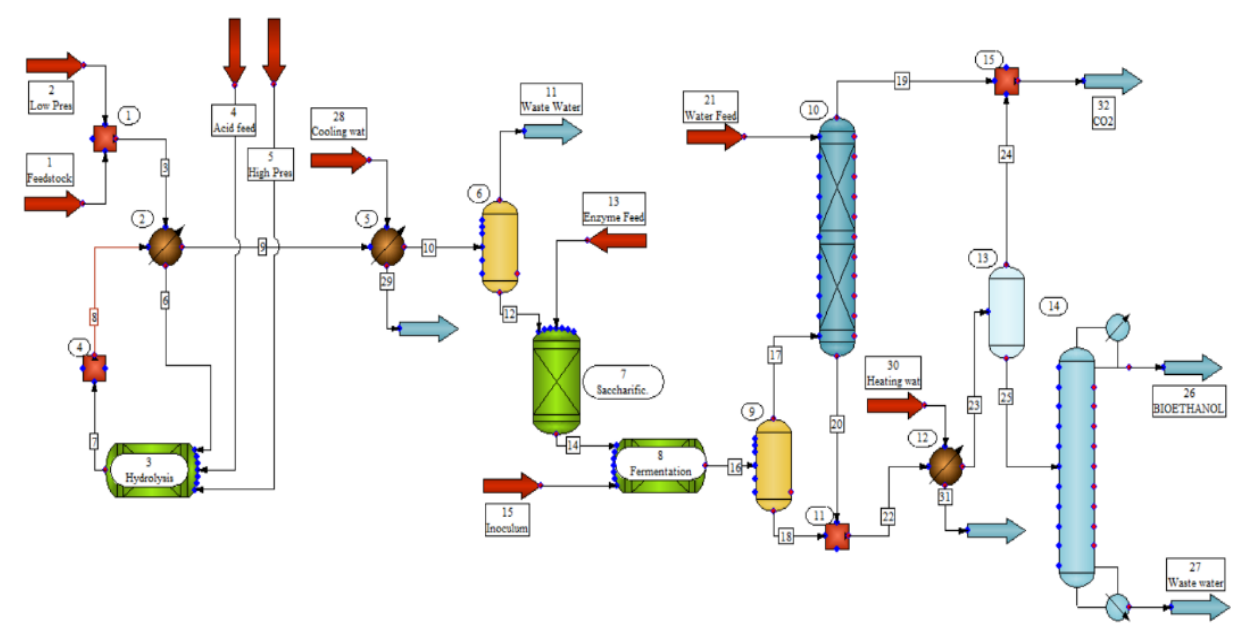

Figure 3. Process flow diagram for bioethanol production from biomass

The production capacity of the plant is approximately $3,681 \mathrm{~kg} / \mathrm{h}$ bioethanol (equivalent to an annual production of 30,000 tons/year). Sulphuric acid is used as catalyst in this process. The purity of the ethanol obtained is $92.38 \%$ (by weight). The mixture of raw-material (Stream 1) and the lowpressure steam (Stream 2) is sent to a heat exchanger (Unit 2). It uses as a heating agent the heat given off by the reaction products, raising the flow temperature from $96.64^{\circ} \mathrm{C}$ to $100^{\circ} \mathrm{C}$. The slightly impure stream together with the acid stream (Stream 4) and the high-pressure steam (Stream 5) are transferred to a reactor (Unit 3). The steam characteristics are $268^{\circ} \mathrm{C}$ and 13 atm. In the equilibrium reactor, the hydrolysis of the cellulosic raw-material takes place, in which most of the hemicellulose is converted to xylose. The reactor is considered to be adiabatic. The remaining cellulose and hemicellulose and all lignin will remain unconverted through the hydrolysis process. Because the conversion is done by fermenting sugars, the process cannot convert non-carbohydrate components from biomass (such as lignin and proteins). The gaseous flow leaves the reactor at $217.17^{\circ} \mathrm{C}$ and $12.1 \mathrm{~atm}$. Stream 9 reaches a heat exchanger that uses water as a cooling agent, decreasing the flow temperature from $217.17^{\circ} \mathrm{C}$ to $190^{\circ} \mathrm{C}$. A separator (Unit 6) is present between the hydrolysis reactor and the saccharification reactor (Unit 7). The separator is an isentropic flash working at $1 \mathrm{~atm}$. It is operated at atmospheric pressure to evacuate part of the water and some by-products. The liquid (Stream 12) leaving the separator together with a stream of enzymes is sent to a second reactor (Unit 7). The saccharification reactor converts cellulose and cellobiose into sugars, such as glucose. The reactor works isothermally at $65^{\circ} \mathrm{C}$. The stream leaving the second reactor (Stream 14) and the inlet 
stream containing the fermentative bacteria (Stream 15) are mixed in a third reactor. Thus, the fermentation process of the formed sugars takes place in the equilibrium reactor (Unit 8). A second flash (Unit 9) is used after the fermentation reactor to separate the condensable (most of the $\mathrm{CO}_{2}$ ). This gas-liquid separator works at $1 \mathrm{~atm}$ and $41^{\circ} \mathrm{C}$. A scrubber with 4 stages (Unit 10) is used to separate the ethanol and the water contained in the gas stream (Stream 17) coming from the flash separator (Unit 9). A flow-rate of $5,026.68 \mathrm{~kg} / \mathrm{h}$ water (Stream 21) with a temperature of $26^{\circ} \mathrm{C}$ and a pressure of $1 \mathrm{~atm}$ is fed on the first stage, while the gas flow (Stream 17) with a temperature of $41^{\circ} \mathrm{C}$ and a pressure of $1 \mathrm{~atm}$ enters on the last stage; At the top of the column is recovered most of the $\mathrm{CO}_{2}$ (Stream 19) in the form of vapours. The liquid flow at the bottom of the distillation column (Stream 20) and the liquid at the bottom of the separator (Stream 18) are mixed; the mixed stream is preheated from $41^{\circ} \mathrm{C}$ to $100^{\circ} \mathrm{C}$, using a heat exchanger (Unit 12). Another flash is used to separate all the carbon dioxide in the form of vapours (Stream 24). The impure ethanol (Stream 25 ) is directed to a distillation column (Unit 14). This unit has 34 plates, the feed stage being stage number 5 . This column separates the ethanol as distillate. The specifications used for this column are: distillate component (i.e. ethanol) recovery $99.99 \%$, bottom component (i.e. water) recovery $98.90 \%$. All the $\mathrm{CO}_{2}$ recovered together with a stream of hydrogen produced by the process of electrolysis of water can be used to produce ethanol again. Finally, all the water flows leaving the process are mixed and sent to a waste-water treatment plant. ChemCAD process simulator (version 7) was used to simulate the above described process using the NRTL thermodynamic package. The reactions taking place in the biomass conversion to ethanol are reported in Table 7.

Table 7. Main reactions considered in bioethanol production from biomass

\begin{tabular}{|c|c|c|}
\hline $\begin{array}{l}\text { Reaction } \\
\text { section }\end{array}$ & Reaction & $\begin{array}{r}\text { Fractional } \\
\text { conversion } \\
\text { used in } \\
\text { ChemCAD } \\
\end{array}$ \\
\hline \multirow{5}{*}{$\begin{array}{l}\frac{n}{n} \\
\frac{n}{2} \\
\frac{0}{0} \\
\text { 조 }\end{array}$} & Cellulose $+\mathrm{H}_{2} \mathrm{O} \rightarrow$ Glucose & 0.007 \\
\hline & Cellulose $+0.5 \mathrm{H}_{2} \mathrm{O} \rightarrow 0.5$ Cellobiose & 0.007 \\
\hline & Hemicellulose $+\mathrm{H}_{2} \mathrm{O} \rightarrow$ Xylose & 0.925 \\
\hline & Hemicellulose $\rightarrow$ Furfural $+\mathrm{H}_{2} \mathrm{O}$ & 0.05 \\
\hline & Acetate $\rightarrow$ Acetic acid & 1 \\
\hline \multirow{3}{*}{ ن } & Cellulose $+\mathrm{H}_{2} \mathrm{O} \rightarrow$ Glucose & 0.94 \\
\hline & Cellulose $+0.5 \mathrm{H}_{2} \mathrm{O} \rightarrow 0.5$ Cellobiose & 0.012 \\
\hline & Cellobiose $+\mathrm{H}_{2} \mathrm{O} \rightarrow 2$ Glucose & 1 \\
\hline
\end{tabular}


INVESTIGATION, SIMULATION AND COMPARISON OF VARIOUS ROUTES FOR BIOETHANOL PRODUCTION

\begin{tabular}{|c|c|c|}
\hline $\begin{array}{l}\text { Reaction } \\
\text { section }\end{array}$ & Reaction & $\begin{array}{r}\text { Fractiona } \\
\text { conversion } \\
\text { used in } \\
\text { ChemCAD } \\
\end{array}$ \\
\hline \multirow{11}{*}{ 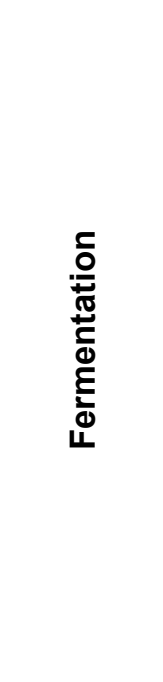 } & Glucose $\rightarrow 2 \mathrm{CH}_{3} \mathrm{CH}_{2} \mathrm{OH}+2 \mathrm{CO}_{2}$ & 0.95 \\
\hline & $3 \mathrm{Xylose} \rightarrow 5 \mathrm{CH}_{3} \mathrm{CH}_{2} \mathrm{OH}+5 \mathrm{CO}_{2}$ & 0.85 \\
\hline & Glucose $+\mathrm{H}_{2} \mathrm{O} \rightarrow 2$ Glycerol $+\mathrm{O}_{2}$ & 0.004 \\
\hline & Glucose $+2 \mathrm{CO}_{2} \rightarrow 2$ Succinic acid $+\mathrm{O}_{2}$ & 0.006 \\
\hline & Glucose $\rightarrow 3$ Acetic acid & 0.015 \\
\hline & Glucose $\rightarrow 2$ Lactic acid & 0.002 \\
\hline & 3 Xylose $+5 \mathrm{H}_{2} \mathrm{O} \rightarrow 5$ Glycerol $+2.5 \mathrm{O}_{2}$ & 0.003 \\
\hline & Xylose $+\mathrm{H}_{2} \mathrm{O} \rightarrow$ Xylitol $+0.5 \mathrm{O}_{2}$ & 0.046 \\
\hline & $3 \mathrm{Xylose}+5 \mathrm{CO}_{2} \rightarrow 5$ Succinic acid $+2.5 \mathrm{O}_{2}$ & 0.000 \\
\hline & 2 Xylose $\rightarrow 5$ Acetic acid & 0.014 \\
\hline & 3 Xylose $\rightarrow 5$ Lactic acid & 0.002 \\
\hline
\end{tabular}

A comparison with other renewable process for ethanol production is described in this section as we can see in Figure 4 and Figure 5. The comparison method refers to ethanol production by thermo-catalytic hydrogenation of carbon dioxide.

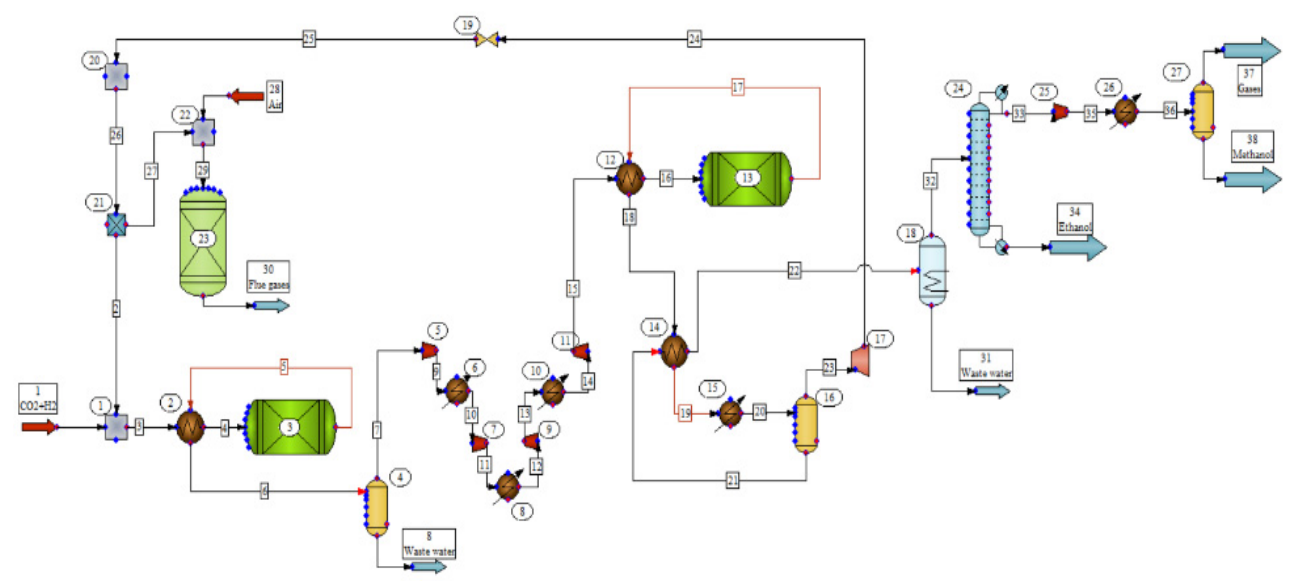

Figure 4. Process flow diagram for bioethanol production from $\mathrm{CO}_{2}$ and $\mathrm{H}_{2}$ 


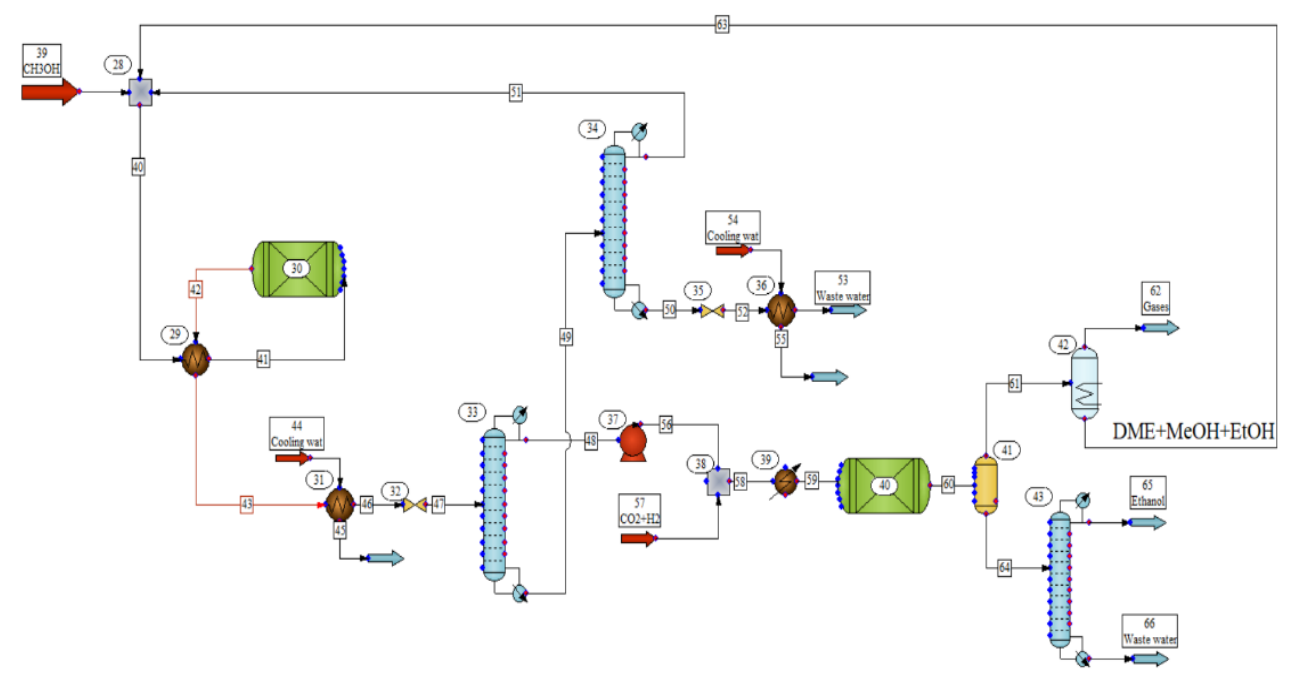

Figure 5. Process flow diagram for bioethanol production from methanol

The reaction mechanism consists of:

- hydrogenation of carbon dioxide to carbon monoxide and water (reverse Water Gas Shift (WGS) reaction)

(R1): $\mathrm{CO}_{2}+\mathrm{H}_{2} \leftrightarrow \mathrm{CO}+\mathrm{H}_{2} \mathrm{O}$ and

- syngas conversion to ethanol and water

(R2): $2 \mathrm{CO}+4 \mathrm{H}_{2} \leftrightarrow \mathrm{C}_{2} \mathrm{H}_{5} \mathrm{OH}+\mathrm{H}_{2} \mathrm{O}$.

After the WGS reactor, the resulting water is removed from the system and the remaining gas is introduced into alcohol synthesis reactor, in which the methanol is recycled, the following reactions taking place.

- (R3): syngas conversion to methanol $\mathrm{CO}+2 \mathrm{H}_{2} \leftrightarrow \mathrm{CH}_{3} \mathrm{OH}$,

- (R4): methanol hydrogenation with ethanol and water formation $\mathrm{CH}_{3} \mathrm{OH}+\mathrm{CO}+\mathrm{H}_{2} \leftrightarrow \mathrm{C}_{2} \mathrm{H}_{5} \mathrm{OH}+\mathrm{H}_{2} \mathrm{O}$, and

- (R5): ethanol hydrogenation with propanol and water formation (side reaction) $\mathrm{C}_{2} \mathrm{H}_{5} \mathrm{OH}+\mathrm{CO}+2 \mathrm{H}_{2} \leftrightarrow \mathrm{C}_{3} \mathrm{H}_{7} \mathrm{OH}+\mathrm{H}_{2} \mathrm{O}$.

This route was also modelled using ChemCAD process simulator (version 7). The production capacity of the plant is $3681 \mathrm{~kg} / \mathrm{hour}$ of ethanol, the desired purity of the ethanol being higher than $90 \%$ by weight. The PSRK and Mixed Model packages were used for the enthalpies. The raw-materials introduced in the system are: carbon dioxide, $18,369.29 \mathrm{~kg} / \mathrm{h}$, with a pressure of $24.6 \mathrm{~atm}$ and a temperature of $50^{\circ} \mathrm{C}$ and hydrogen, $2,510.72 \mathrm{~kg} / \mathrm{h}$, with a 
pressure of 24.6 atm and a temperature of $50^{\circ} \mathrm{C}$. The $\mathrm{CO}_{2}$ and $\mathrm{H}_{2}$ mixture is sent to a heat exchanger that uses as heating agent the heat given off by the reaction products, raising the flow temperature from $37.48^{\circ} \mathrm{C}$ to $487.8^{\circ} \mathrm{C}$. The stream is introduced into a reactor operated at $560^{\circ} \mathrm{C}$ and $24.6 \mathrm{~atm}$. The reactor is considered to work isothermal, the reactions, (R1) and (R2) occurring in series. The raw-materials conversion is $62 \%$. The reaction products leave the reactor at $560^{\circ} \mathrm{C}$, but using a cooler, the stream temperature is decreased to $112^{\circ} \mathrm{C}$. The products are sent to a phase separator, in this case, a gasliquid separator, operating at a $30^{\circ} \mathrm{C}$ and $15.8 \mathrm{~atm}$. The resulting vapours suffer a compression process. $85 \%$ efficiency was considered for the compressors the pressure being increased from $19.7 \mathrm{~atm}$ to $78.9 \mathrm{~atm}$. Four compressors with four intercooling heat exchangers are used. The pressure was increased with 20 bars after each compression step. This mixture is heated, raising the temperature from $114.56^{\circ} \mathrm{C}$ to $200.94^{\circ} \mathrm{C}$. The stream is furthermore introduced into another reactor operated isothermally at $300^{\circ} \mathrm{C}$ and $78.9 \mathrm{~atm}$. A conversion of $85 \%$ is achieved in this unit. The reaction products are introduced into a heat exchanger, the temperature decreasing to $211.9^{\circ} \mathrm{C}$. The gas-liquid separation occurs at $50^{\circ} \mathrm{C}$ and 98.6 atm in a flash unit. The resulting vapours, at the top of the separator, are compressed until they reach a pressure of $78.9 \mathrm{~atm}$. The compressor is an adiabatic compressor having an efficiency of $80 \%$. The vapour stream is mixed with the input stream of the process. A percentage of $77.25 \%$ of this stream is recycled back to the process, while the remaining stream, along with an air stream, is introduced into a Gibbs reactor operated at $1000^{\circ} \mathrm{C}$ and $19.7 \mathrm{~atm}$. The remaining liquid is sent to a distillation column with 20 plates, the feed stage being stage 10; the separation of ethanol from methanol takes place in this column. The distillate temperature was considered $26.5^{\circ} \mathrm{C}$, ethanol component mole fraction being 0.997 . Part of the methanol is recycled, being mixed with the streams at the entrance to the process while the other part is directed to the dimethyl ether (DME) production process, which will generate additional ethanol. Thus, slightly impure methanol is mixed with a recycled stream containing more than $95 \%$ ethanol, methanol, and water. The mixture reaches a heat exchanger that uses as heating agent the heat released by the reaction products, raising the flow temperature from $100^{\circ} \mathrm{C}$ to $250^{\circ} \mathrm{C}$. The stream is introduced in a reactor operated at $280^{\circ} \mathrm{C}$ and $14.5 \mathrm{~atm}$, the methanol conversion being $80 \%$. Reaction products and unreacted ethanol are cooled from $113^{\circ} \mathrm{C}$ to $89^{\circ} \mathrm{C}$ in a heat exchanger using cooling water. The cooling flow pressure (i.e. $14.5 \mathrm{~atm}$ ) is reduced using a valve up to $7.3 \mathrm{~atm}$. The mixture is furthermore introduced in a distillation column with 24 stages, the feed stage being stage number 13; the separation of DME as distillate takes place in a proportion of $80 \%$. The specifications used for this column are: reflux ratio 0.36 , bottom product temperature $153^{\circ} \mathrm{C}$. Un-separated DME, methanol, ethanol and water from the bottom of the column are sent to a second 
distillation column, having 28 stages, the input feed being on stage 15 . The separation of waste-water from the mixture takes place here, the mixture being recycled and mixed with the input methanol stream. The specifications used for this column are: distillate temperature $75^{\circ} \mathrm{C}, 99.99 \%$ water in the bottom stream. The separated DME stream from the first column is mixed with a stream containing $\mathrm{CO}_{2}$ and $\mathrm{H}_{2}$, then preheated to $180^{\circ} \mathrm{C}$, using a heat exchanger. The stream is sent to a reactor operated at $180^{\circ} \mathrm{C}$. A DME conversion of $72 \%$ was assumed here. The slightly formed ethanol will be separated from the vapor stream thus formed, and the rest of the mixture is recycled, mixing with the methanol flow at the beginning of the process. Impure ethanol is fed to a distillation column having 20 stages, the input stream being fed on stage 10 , where the separation of ethanol as distillate takes place. Finally, all the waste-water streams leaving the process are mixed and sent to the wastewater treatment plant.

\section{REFERENCES}

1. G. Whitten. Air Quality and Ethanol in Gasoline, Smog Reyes, December, 2004.

2. M. Arshadi, H. Grundberg H. Biochemical production of bioethanol. Handbook of Biofuels Production, 2011, 199 - 220.

3. Renewable Fuels Association, http://www.ethanolrfa.org (Accessed in June 2020).

4. Natural Resources Defense Council, Unlocking the Promise of Ethanol, February 2006.

5. M. Balat, H. Balat, C. Öz. Progr. Energ. Combust. Sci., 2008, $551-73$.

6. H.J. Arpe, K. Weissermel K. Industrial Organic Chemistry, 2010, Vol.8, 393.

7. https://epure.org (Accessed in February 2020).

8. U.S. Department of Energy, Energy Efficiency and Renewable Energy (EERE) Biomass Program, Feedstock Types, 2012.

9. P.C. Badger. Ethanol from cellulose: A general review, 2002, 17 - 21.

10. V.S. Sikarwara, M. Zhaoa, P.S. Fennelld, N. Shahd, J.A. Edward. Progr. Energ. Combust. Sci., 2017, $189-248$.

11. S. Clarke, F, Preto, Biomass densification for energy production, Ontario Ministry of Agriculture and Food factsheet, 2011 (Accessed March 2020).

12. S. Brethauer, M. H. Studer. Int. J. Chem., 2015, $572-581$.

13. C.E. Wyman C.E. Handbook on bioethanol. Production and utilization. Washington, DC, 1996.

14. D. Pimentel, T.W. Patzek T.W. Nat. Resour. Res., 2005, 65 - 70.

15. M. Arshadi, H. Grundberg. Processes and Technologies. Biochemical production of bioethanol, Handbook of Biofuels Production, 2011.

16. http://www.bioethanol.prosim.net/E10_BioethanolPlant.pdf (Accessed in March 2020).

17. K. Atsonios, K.D. Panopoulos, E. Kakaras. Int. J. Hydrog. Energ., 2016, 792 - 80. 